\title{
Calcium homeostasis modulator 1 (CALHM1) reduces the calcium content of the endoplasmic reticulum (ER) and triggers ER stress
}

\author{
Sonia GALLEGO-SANDÍN, María Teresa ALONSO and Javier GARCÍA-SANCHO ${ }^{1}$ \\ Instituto de Biología y Genética Molecular (IBGM). Universidad de Valladolid y Consejo Superior de \\ Investigaciones Científicas (CSIC). C/ Sanz y Forés, 3. 47003-Valladolid, Spain
}

Short title: CALHM1 reduces ER calcium and triggers ER stress responses

${ }^{1}$ To whom correspondence should be addressed at: Dr. J. García-Sancho, IBGM, c/Sanz y Forés s/n, 47003-Valladolid, Spain. Phone: 34-983-423084; Fax: 34-983-421800; e-mail: jgsancho@ibgm.uva.es

\section{SYNOPSIS}

Calcium homeostasis modulator 1 (CALHM1), a membrane protein with similarity to NMDA receptor channels that localizes in the plasma membrane and the endoplasmic reticulum (ER)of neurons, has been shown to generate a plasma membrane $\mathrm{Ca}^{2+}$ conductance and has been proposed to influence Alzheimer Disease risk. In the present study we have investigated the effects of CALHM1 on intracellular $\mathrm{Ca}^{2+}$ handling in HEK293T cells by using targeted aequorins for selective monitorization of $\mathrm{Ca}^{2+}$ transport by organelles. We find that CALHM1 increases $\mathrm{Ca}^{2+}$ leak of the ER and, more importantly, reduces ER $\mathrm{Ca}^{2+}$ uptake by decreasing both the transport capacity and the $\mathrm{Ca}^{2+}$ affinity of the sarco/endoplasmic reticulum $\mathrm{Ca}^{2+}$ ATPase (SERCA). As a result, the $\mathrm{Ca}^{2+}$ content of the ER is drastically decreased. This reduction of the $\mathrm{Ca}^{2+}$ content of the ER triggered the unfolded protein response (UPR) with induction of several ER stress markers, such as CHOP, ERdj4, GRP78 and XBP1. Thus, CALHM1 might provide a relevant link between $\mathrm{Ca}^{2+}$ homeostasis disruption, ER stress and cell damage in the pathogenesis of neurodegenerative diseases.

\section{KEYWORDS:}

CALMH1, Endoplasmic reticulum, ER stress, unfolding protein response, Azheimer disease, ER leak, Calcium, intracellular calcium stores, aequorin, SERCA, Sarco/endoplasmic Ca2+ ATPase, Calcium homeostasis modulator 1

\section{ABBREVIATIONS FOOTNOTE:}

Abbreviations used : AD, Alzheimer disease, ER, endoplasmic reticulum; PM, plasma membrane; CALHM1, Calcium homeostasis modulator $1 ;\left[\mathrm{Ca}^{2+}\right]_{\mathrm{C}}$, cytosolic $\mathrm{Ca}^{2+}$ concentration; $\left[\mathrm{Ca}^{2+}\right]_{\mathrm{ER}}, \mathrm{Ca}_{2+}$ concentration inside ER; TBS, Tris-Buffered Saline; SERCA, Sarco/Endoplasmic Reticulum Ca2+ATPase; GFP, Green Fluorescent Protein; GA, chimeric GFP-aequorin protein; CALHM1-Cherry, chimeric CALHM1-mCherry Fluorescent Protein; TBH, 2,5-di-tert-butylbenzohydroquinone; ermutGA, low $\mathrm{Ca} 2+$ affinity ER-targeted GA; lucGA, luciferase-GFP-aequorin fusion protein (cytosolic aequorin); CCh, carbachol; DAPI, Diamidino-2-phenylindole. UPR, unfolded protein response. 


\section{INTRODUCTION}

$\mathrm{Ca}^{2+}$ signaling is a key regulation pathway in animal cells. In the nervous system, $\mathrm{Ca}^{2+}$ signaling is essential for learning and memory, neurotransmitter action and synaptic activity, gene expression, excitotoxicity and cell death $[1,2]$. Perturbations in $\mathrm{Ca}^{2+}$ signalling have been proposed to play a role in the pathogenesis of neurodegenerative disorders, including Alzheimer disease (AD) . The proposed alterations refer both to $\mathrm{Ca}^{2+}$ entry [2-6] or to intracellular $\mathrm{Ca}^{2+}$ handling by the endoplasmic reticulum [2, 7-10] and mitochondria [5, 11-13]. Possible involvement of presenilins on $\mathrm{Ca}^{2+}$ homeostasis and of their mutants on the pathogenesis of $\mathrm{AD}$ has received particular attention [14]. presenilins seem to interact and modulate both, calcium influx into the endoplasmic reticulum (ER) via SERCA [15-17], and calcium exit from the ER via interactions with the ryanodine receptors $[2,18,19]$, nositol 1,4,5 trisphosphate receptors $[15,20,21]$ or endogenous leak channels $[10,22,23]$.

A novel gene called calcium homeostasis modulator 1 (CALHM1), which is expressed preferentially in the nervous system, has been recently proposed to influence $\mathrm{Ca}^{2+}$ homeostasis, amyloid-betapeptide levels and AD risk [24]. CALHM1 shares strong similarities with the selectivity filter of the NMDA receptor channel and is able to generate a plasma membrane (PM) $\mathrm{Ca}^{2+}$ conductance. CALHM1 P86L polymorphism was reported to be associated with late-onset AD susceptibility [24]. This proposal has been very controversial and a recent meta-analysis has established that the CALHM1 P86L polymorphism is not a genetic determinant of AD but may modulate age of onset by interacting with the effect of the $\varepsilon 4$ allele of the APOE gene [25].

Since CALHM1 localizes to the ER as well as to the PM, it has been speculated without experimental evidence that CALHM1 might increase the $\mathrm{Ca}^{2+}$ leak from the ER $[18,24]$. This possibility is very interesting, as the increased $\mathrm{Ca}^{2+}$ leak would lead to a decrease of the $\mathrm{Ca}^{2+}$ concentration inside ER $\left(\left[\mathrm{Ca}^{2+}\right]_{\mathrm{ER}}\right)$, which, in turn, could produce ER stress and unfolding protein response (UPR) [26, 27], a reaction that triggers both homeostatic and pathophysiological mechanisms [13, 28, 29]. Here we directly address this hypothesis by selective monitoring $\mathrm{Ca}^{2+}$ transport through the ER membrane using ER-targeted aequorin $\mathrm{Ca}^{2+}$ probes. We find that CALHM1 both increased $\mathrm{Ca}^{2+}$ leak and decreased $\mathrm{Ca}^{2+}$ pumping into the ER. As a result, $\left[\mathrm{Ca}^{2+}\right]_{\mathrm{ER}}$ decreases and an UPR cascade is activated.

\section{MATERIALS AND METHODS}

\section{Plasmids}

Human CALHM1and its P86L mutant, both cloned in pcDNA3.1 Myc-His, were a generous gift from Dr. Philippe Marambaud [24]. In order to trace the subcellular localization of CALHM1, the CALHM1-mCherry fluorescent protein (CALHM1-Cherry) fusion was generated by cutting pcDNA3.1-CALHM1 with EcoRV and XhoI. Cherry was amplified by PCR with a forward primer 5'atcGTGAGCAAGGGCGAGGAGGATAAC-3' which introduces half a site of an EcoRV site and a reverse primer 5'-cactcgagTCACTTGTACAGCTCGTCCAT-3' which introduces a XhoI restriction site at the 3' end of Cherry. The fragment was cut with XhoI and fused in frame at the 3 ' end of CALHM, in pcDNA3.1.

\section{Cell culture and gene transfection}

HEK293T (ATCC CRL-11268) cells were maintained in DMEM (Invitrogen) supplemented with 10\% fetal bovine serum, $2 \mathrm{mM}$ L-glutamine, $100 \mu \mathrm{g} / \mathrm{ml}$ streptomycin, $100 \mathrm{U} / \mathrm{ml}$ penicillin and $5 \mu \mathrm{g} / \mathrm{ml}$ Plasmocin ${ }^{\mathrm{TM}}$ (InvivoGen) at $37{ }^{\circ} \mathrm{C}$, under an air $/ 5 \% \mathrm{CO}_{2}$ mixture. For aequorin experiments, about 6$10 \times 10^{4}$ cells were seeded on poly-L-lysine coated 4 well-plates and co-transfected with pcDNA3.1CALHM1 and aequorin cDNA (ratio 2:1) using Lipofectamine ${ }^{\mathrm{TM}} 2000$ (Invitrogen). The experiments were performed at 6 or $24 \mathrm{~h}$ after transfections. For quantitative RT-PCR experiments (see below), 
$5 \times 10^{5}$ cells were seeded on $35 \mathrm{~mm}$ plates and transfected with pcDNA3.1-CALHM1 or the empty vector.

\section{Expression of fluorescent proteins and immunofluorescence}

The procedure used was as described previously [30]. Briefly, HEK293T cells were fixed with 4\% paraformaldehyde and blocked with 10\% goat serum and 0.5\% TritonX-100 in Tris-buffered saline (TBS) for $20 \mathrm{~min}$. The fixed cells were incubated overnight at $4^{\circ} \mathrm{C}$ with the primary antibody diluted in $1 \%$ goat serum and $0.5 \%$ TritonX-100 in TBS. A rabbit anti-CALHM1 polyclonal antibody (from Sigma) was used at 1:1000. After washing with $10 \%$ goat serum and $0.5 \%$ TritonX-100 in TBS, the cells were incubated (45 min at room temperature) with Alexa Fluor 488 or Alexa Fluor 568conjugated goat anti-rabbit IgG (1:500 or 1:200 respectively, from Molecular Probes) in 1\% goat serum and $0.5 \%$ TritonX-100 in TBS. Nuclei were stained with 4',6-diamidino-2-phenylindole (DAPI). Cells were mounted in Vectashield ${ }^{\mathrm{R}}$ (Vector) and observed with a C-Apochromat $63 \mathrm{X}$ waterinmersion objective (NA, 1.20) in a Zeiss Axioplan Z microscope. The Zeiss ApoTome ${ }^{\mathrm{TM}}$ system was used for optical sectioning. Expression of CALHM1 was analysed by imaging the green (Ex, 490/20; $\mathrm{Em}, 540 / 50 \mathrm{~nm}$ ) and the red fluorescences (Ex 560/40; Em: 615/45 nm) in the fixed cells.

\section{Measurement of aequorin bioluminescence}

The chimeric GFP-aequorins (GA) localized to the cytosol (luciferase-GFP-aequorin fusion protein, lucGA) or the low $\mathrm{Ca}^{2+}$ affinity probe targeted to ER (ermutGA) have been previously described [ 31 , 32]. Cells expressing lucGA were incubated for $1 \mathrm{~h}$ at room temperature with $1 \mu \mathrm{M}$ coelenterazine in a standard incubation medium with the following composition (in $\mathrm{mM}$ ): $\mathrm{NaCl}, 145 ; \mathrm{KCl}, 5 ; \mathrm{CaCl}_{2}, 1$; $\mathrm{MgCl}_{2}$, 1; glucose, 10; sodium-HEPES, 10; $\mathrm{pH}$ 7.4. For $\left[\mathrm{Ca}^{2+}\right]_{\mathrm{ER}}$ measurements, cells expressing ermutGA [33] were reconstituted with $1 \mu \mathrm{M}$ coelenterazine $\mathrm{n}$ [34] by incubation for $1 \mathrm{~h}$ at room temperature in $\mathrm{Ca}^{2+}$-free medium containing $0.5 \mathrm{mM}$ EGTA and $10 \mu \mathrm{M}$ of the SERCA inhibitor 2,5ditert-butyl-benzohydroquinone (TBH) [35]. The experiment was started by washing the TBH with standard medium containing $1 \mathrm{mM} \mathrm{Ca}^{2+}$.Aequorin photoluminescence was measured using a Cairn Research luminescence spectrophotometer as previously described [33]. Calibrations in $\left[\mathrm{Ca}^{2+}\right]$ were done using the constants' values already published $[33,36]$. All the measurements were performed at $22^{\circ} \mathrm{C}$. In the experiments using PM-permeabilized cells, perfusion was performed with intracellularlike medium with the following composition (in $\mathrm{mM}$ ): $\mathrm{KCl}, 140 ; \mathrm{KH}_{2} \mathrm{PO}_{4}, 1 ; \mathrm{MgCl}_{2}, 1 ; \mathrm{Mg}$-ATP, 1 ; Na-succinate, 2; sodium-HEPES, 20; $\mathrm{pH} 7.0$, and different $\mathrm{Ca}^{2+}$ concentrations and other additions as detailed below. First, the cells were perfused at about $5 \mathrm{ml} / \mathrm{min}$ with $\mathrm{Ca}^{2+}$-free medium and, then, PM was permeabilized by perfusion with $60 \mu \mathrm{M}$ digitonin in $\mathrm{Ca}^{2+}$-free (containing $2 \mathrm{mM}$ EGTA) intracellular-like medium for $2 \mathrm{~min}$. The solution was, then, switched to intracellular-like medium without digitonin and containing 20-1000 $\mathrm{nM} \mathrm{Ca}^{2+}$ buffered with EGTA [37] or $20 \mu \mathrm{M} \mathrm{Ca}^{2+}$, for 3-5 min and $\mathrm{Ca}^{2+}$ refilling of the ER was monitored from the emitted photoluminescence. Then, the effects of different test solutions were investigated by perfusion in intracellular-like medium (see Figure legends).

\section{Calcium imaging}

The procedure used was as described previously [30, 38, 39]. Briefly, HEK293T cells transfected with CALHM1-Cherry were loaded with $4 \mu \mathrm{M}$ fura2-acetoxymethyl ester (AM) (Molecular Probes) for $1 \mathrm{~h}$ at room temperature in standard incubation medium (see above). Cells were then washed with fresh medium and the cell-containing coverslips mounted under the microscope (Nikon Diaphot). Test solutions were applied by continuous perfusion at 2-3 ml/min. For fluorescence measurements, cells were alternately epi-illuminated at 340 and $380 \mathrm{~nm}$ and light emitted above 520-nm was recorded using a Hamamatsu Digital Camera C4742-98 handled by Simple PCI 6.6 Hamamatsu software. Consecutive frames obtained at 340 and $380 \mathrm{~nm}$ excitation were ratioed pixel by pixel using imageJ 
software and calibrated in $\left[\mathrm{Ca}^{2+}\right]_{\mathrm{C}}$ by comparison with fura- 2 standards. Expression of CALHM1Cherry was analysed by imaging of the fluorescence at $555-\mathrm{nm}$.

\section{Quantitative RT-PCR}

Relative expression levels of ER stress genes was assessed by quantitative RT-PCR. Total RNA was isolated from cells $24 \mathrm{~h}$ after transfection using Trizol reagent (Invitrogen). 1-2 ug RNA was reverse transcribed using M-MLV-RT (Applied Biosystems) and random hexamer as primers. Amplifications of $100 \mathrm{ng}$ cDNA were performed in triplicates in $20 \mu \mathrm{l}$ reaction mixtures containing $200 \mathrm{nM}$ primers and SYBR Green PCR master mix (Applied Biosystems). Primers used were: human GRP78/BiP forward, 5'-CGGGCAAAGATGTCAGGAAAAG-3' and reverse 5'TTCTGGACGGGCTTCATAGTAGAC-3'; human Chop forward 5'ACCAAGGGAGAACCAGGAAACG-3' and reverse 5'-TCACCATTCGGTCAATCAGAGC-3'; human ERdj4 forward 5'-TGGTGGTTCCAGTAGACAAAGG-3' and reverse 5'CTTCGTTGAGTGACAGTCCTGC-3' [40, 41] and human GAPDH forward 5'ACACCCACTCCTCCACCTTTG-3' and reverse 5'-CATACCAGGAAATGAGCTTGACAA-3'. The PCR was run on a Light Cycler 480 system (Roche) and the conditions were: $95^{\circ} \mathrm{C}$ for $15 \mathrm{~min}$, $95^{\circ} \mathrm{C}$ for $15 \mathrm{sec}, 60^{\circ} \mathrm{C}$ for $30 \mathrm{sec}, 72^{\circ} \mathrm{C}$ for $30 \mathrm{sec}, 72^{\circ} \mathrm{C} 1 \mathrm{~min}$, with 40 cycles of amplification. Relative gen expression was determined with the $2^{-\Delta \Delta \mathrm{Ct}}$ method [42].

\section{Statistical analysis}

Data are expressed as mean \pm S.E.M. Statistical significance was evaluated by Student's t-test or oneway ANOVA using GraphPad InStat3 software.

\section{RESULTS}

The PM permeability to $\mathrm{Ca}^{2+}\left(\mathrm{P}_{\mathrm{Ca}}\right)$ was assessed from the size of the $\left[\mathrm{Ca}^{2+}\right]_{\mathrm{C}}$ overshoots on transition from medium with no $\mathrm{Ca}^{2+}$ to medium containing $2 \mathrm{mM} \mathrm{Ca}^{2+}$ (Fig. 1). Confirming previous reports [1, 24,43 , expression of CALHM1 increased the $\mathrm{P}_{\mathrm{Ca}}$. In CALHM1 transfected cells the overshoot was increased up to 8 fold after 24 hours of expression (Fig. 1A) and about 2 fold at 6 hours (Fig. 1B). The effect of CALHM1 on $\mathrm{P}_{\mathrm{Ca}}$ was fully blocked by nickel (Fig. 1A). In the cells expressing CALHM1 during $24 \mathrm{~h}$ there was a clear increase of the resting $\left[\mathrm{Ca}^{2+}\right]_{\mathrm{C}}($ Fig. 1A), probably as result of the greatly increased $\mathrm{Ca}^{2+}$ entry, which should follow the increased $\mathrm{P}_{\mathrm{Ca}}$. In our hands, the effects of wild type CALHM1 and the P86L mutant on $\mathrm{Ca}^{2+}$ entry were indistinguishable: the $\Delta\left[\mathrm{Ca}^{2+}\right]_{\mathrm{C}}$ (mean \pm s.e.m.; $\mathrm{n}=4$ ) was $3.99 \pm 0.04$ for the wild type and $3.93 \pm 0.21$ for the mutant (results not shown).

Next we compared the uptake into the ER in control and in CALHM1-transfected cells. In order to minimize non-specific deleterious effects, the experiments were performed in cells expressing CALHM1 for only 6 hours. Typical results are illustrated in Fig. 2A, and averaged values are summarized in Fig. 2B-D. $\mathrm{Ca}^{2+}$ uptake in the ER was faster in the CALHM1-transfected cells than in the control cells (Fig. 2A; Fig. 2C); this is, most probably, attributable to a faster $\mathrm{PM} \mathrm{Ca}^{2+}$ entry and, consequently, to a larger increase of $\left[\mathrm{Ca}^{2+}\right]_{\mathrm{C}}$ (Fig. 1). However, the ER accumulation of $\mathrm{Ca}^{2+}$ at the steady state was significantly decreased (Fig. 2A and Fig. 2B). This decrease suggests that either the $\mathrm{Ca}^{2+}$ pumping into the ER is decreased or the ER $\mathrm{Ca}^{2+}$ leak is increased. An approximate measurement of the $\mathrm{Ca}^{2+}$ exit from the ER has been attempted in the experiments of Fig. 2A by removing external $\mathrm{Ca}^{2+}$ once the ER had been refilled (but note that this fluxes measure serial exit from the ER and through the PM). These measurements revealed that the $\mathrm{Ca}^{2+}$ exit from the ER was 1.8 times faster in the CALHM1-transfected cells (Fig. 2D).

ER passive permeability (leak) can be studied directly in PM-permeabilized cells with blocked $\mathrm{Ca}^{2+}$ pumping by imposing a $\mathrm{Ca}^{2+}$ concentration gradient to drive $\mathrm{Ca}^{2+}$ diffusion. In these experiments cells 
were cotransfected with ermutGA and either CALHM1 or the empty pcDNA3 vector.SERCA pump was irreversibly blocked with thapsigargin. Results are shown in Fig. 3. After PM permeabilization in medium containing digitonin and no $\mathrm{Ca}^{2+}$ (DIGIT.), ER uptake was started by suddenly increasing $\left[\mathrm{Ca}^{2+}\right]$ to $1000 \mu \mathrm{M}$ (Fig. 3A). $\mathrm{Ca}^{2+}$ uptake was quite fast and tended to reach a $\left[\mathrm{Ca}^{2+}\right]_{\mathrm{ER}}$ plateau of about $2 \mathrm{mM}$ at the steady state, with half-times of about $1 \mathrm{~min}$. in the control and $30 \mathrm{~s}$ in the CALHM1-transfected cells. Three minutes later $\mathrm{Ca}^{2+}$ was removed to force $\mathrm{Ca}^{2+}$ exit and $\left[\mathrm{Ca}^{2+}\right]_{\mathrm{ER}}$ decreased quickly, again faster in the CALHM1-transfected than in the control cells (Fig. 3A). The average values ( \pm s.e.m.) of several similar experiments are shown in Fig. 3B. Both influx and efflux were about twice as fast in the CALHM1-transfected cells confirming that ER leak is increased, as it was suggested by the results in the intact cells (Fig. 2E). Another series of experiments using 0.5 instead of $1 \mathrm{mM}$ external $\mathrm{Ca}^{2+}$ gave similar results (see Fig. 3 legend).

Although the increase of $\mathrm{ER} \mathrm{Ca}^{2+}$ leak was clear and statistically significant we though that it was not enough to convincingly explain the decrease in $\left[\mathrm{Ca}^{2+}\right]_{\mathrm{ER}}$ at the steady state. The $\mathrm{Ca}^{2+}$ entry through $\mathrm{PM}$ is faster in the CALHM1-expressing cells (Fig. 1); this should increase $\left[\mathrm{Ca}^{2+}\right]_{\mathrm{C}}$ and favour $\mathrm{Ca}^{2+}$ uptake into the ER (as seen in Fig. 2A and 2C), which would oppose the $\left[\mathrm{Ca}^{2+}\right]_{\mathrm{ER}}$ decrease. The other determinant of $\left[\mathrm{Ca}^{2+}\right]_{\mathrm{ER}}$ is the active $\mathrm{Ca}^{2+}$ uptake by SERCA. We then studied $\mathrm{Ca}^{2+}$ uptake by the ER in PM-permeabilized cells, in which $\left[\mathrm{Ca}^{2+}\right]_{\mathrm{C}}$ can be varied and controlled at wish. Fig. 4 summarizes the results of these experiments. Cells were cotransfected with ermutGA and either the empty pCDNA3 vector or CALHM1. After a brief permeabilization of the PM with digitonin in intracellular-like, $\mathrm{Ca}^{2+}$ free medium (not shown; see Methods), the cells were perfused with medium containing ATP and different $\mathrm{Ca}^{2+}$ concentrations, from 0.02 to $20 \mu \mathrm{M}$, as shown (compare Fig. 4A and Fig. 4B). The uptake was much slower in the CALHM1-transfected cells, especially at the lower $\mathrm{Ca}^{2+}$ concentrations. Fig. 4C shows the kinetics of the rate of uptake $v s \mathrm{Ca}^{2+}$ concentrations. Both, transport capacity and $\mathrm{Ca}^{2+}$ affinity were decreased. $\mathrm{V}_{\max }$ decreased from 50 to $20 \mu \mathrm{M} / \mathrm{s}$ and $\mathrm{K}_{50}$ increased from 0.3 to $0.9 \mu \mathrm{M}$. The $\left[\mathrm{Ca}^{2+}\right]_{\mathrm{ER}}$ reached at the steady state (Fig. 4D) was even more affected by CALHM1 expression, especially near the physiological $\left[\mathrm{Ca}^{2+}\right]_{\mathrm{C}}$ concentrations $\left(10^{-7} \mathrm{M}\right)$, where $\left[\mathrm{Ca}^{2+}\right]_{\mathrm{ER}}$ was decreased almost 7 fold $(\mathrm{p}<0.001)$. It should be kept in mind that both the decreased ER uptake (Fig. 4) and the increased leak (Fig. 2D; Fig. 3) cooperate to decrease $\left[\mathrm{Ca}^{2+}\right]_{\mathrm{ER}}$.

Next we investigated the functional consequences of the reduction $\left[\mathrm{Ca}^{2+}\right]_{\mathrm{ER}}$ by checking whether the cells expressing CALHM1 developed ER stress. First, we wanted to investigate the role of CALHM1 in the activation of the IRE1/XBP1 pathway. Under normal conditions, the mRNA for the transcription factor XBP1 contains a premature stop codon and thus produces an immature protein with a short half-life. During ER stress, the activated IRE1 causes the splicing of XBP1 mRNA into a mature mRNA, which in turn produces the functional transcription factor. In this study we used the ER stress fluorescent reporter XBP1-venus [44], which is only expressed when the IRE1-mediated splicing takes place. Thus, the presence of the green fluorescence in the nucleus indicates, at the single-cell level, the activation of IRE1. In order to monitor also CALHM1 expression at the singlecell level, a CALHM1-Cherry construct was generated and characterized. First, we checked whether the chimeric protein preserved the $\mathrm{Ca}^{2+}$-conducing ability of CALHM1 (Fig. 5A and 5B). For this purpose, cells were transfected with CALHM1-Cherry, loaded with fura-2, and then subjected to a protocol including: i)a $\mathrm{Ca}^{2+}$ overshoot, by suddenly changing the incubation medium from $\mathrm{Ca}^{2+}$-free $(\mathrm{Ca} 0)$ to $\mathrm{Ca}^{2+}$-containing medium $(10 \mathrm{mM} ; \mathrm{Ca} 10)$ and ii)an $\mathrm{ER} \mathrm{Ca}^{2+}$-release by stimulation with 100 $\mu \mathrm{M}$ ATP $+100 \mu \mathrm{M}$ cabachol $(\mathrm{CCh})$ in $\mathrm{Ca}^{2+}$ free medium. Results were analyzed separately in the CALHM1-Cherry-expressing cells (emitting red fluorescence) and in the control cells (non-emitting red fluorescence). The cells expressing CALHM1-Cherry (red trace in Fig. 5A) showed a much bigger $\mathrm{Ca}^{2+}$ overshoot than the control cells (black trace). By contrast, the release from the ER after maximal stimulation $(\mathrm{ATP}+\mathrm{CCh})$ (second $\left[\mathrm{Ca}^{2+}\right]_{\mathrm{C}}$ peak) was smaller in the CALHM1-expresing cells, indicating that their intracellular $\mathrm{Ca}^{2+}$ stores contained less $\mathrm{Ca}^{2+}$. The average values from several experiments are shown in Fig. 5B. The $\mathrm{Ca}^{2+}$ overshoot was 7 fold larger in the CALHM1-expressing cells than in the controls, whereas the agonist-induced release from the stores was about 3 times smaller. These data are in perfect agreement with the values obtained for CALHM1 (Fig. 1-Fig. 3), indicating that the fusion CALHM1-Cherry is a functional protein. 
Activation of gene was studied at the single cell level in cells cotransfected with CALHM1-Cherry and XBP1-venus (a generous gift of Dr. Masayuki Miura). Expression of both genes was closely associated at the single-cell level (Fig. 5C). On the other hand, the control cells expressing only Cherry (without CALHM1) did not activate XBP1 gene (not shown). Fig. 5D summarizes the results of 6 different experiments. The frequency of XBP1-venus-positive cells within the Cherry subpopulation was 60 times larger in the cells transfected with CALHM1-Cherry than in the controls transfected with Cherry $(\mathrm{p}<0.0001)$, thus demonstrating that CALHM1 induces a strong ER stress.

In order to characterize better the ER-stress response, we investigated the activation of h-CHOP, $\mathrm{h}$ ERdj4 and h-GRP78, three genes whose induction during UPR has been well documented [45, 46]. The expression was measured by quantitative RT-PCR (see Methods). Our results, summarized in Fig. 5E, demonstrate a strong induction of all the three genes in CALHM1 expressing cells.

\section{DISCUSSION}

Our results show that CALHM1 induces $\mathrm{Ca}^{2+}$ entry through the PM in HEK293T cells (Fig. 1). This $\mathrm{Ca}^{2+}$ entry was blocked with $\mathrm{Ni}^{2+}$, increased with the time of expression and was able to produce a maintained increase of the resting $\left[\mathrm{Ca}^{2+}\right]_{\mathrm{C}}$. These results confirm previous reports $[24,43]$. Apart from its expression in the PM, a vast majority of CALHM1 was localized into the ER, where its function is unknown. It could form, as it has been speculated [18], a functional $\mathrm{Ca}^{2+}$ channel in the membrane of the ER. Since $\left[\mathrm{Ca}^{2+}\right]_{\mathrm{ER}}$ is far from its electrochemical equilibrium, this channel would facilitate the leak of $\mathrm{Ca}^{2+}$ out of this organelle.

By using ER-targeted aequorin, we have been able to directly measure the $\mathrm{Ca}^{2+}$ fluxes in this compartment. By removing external $\mathrm{Ca}^{2+}$ in order to drive exit from the cells, we evidence that CALHM1 does also increase the exit of $\mathrm{Ca}^{2+}$ from the ER in intact cells (Fig. 2A, and 2D). Using PMpermeabilized cells in which ER $\mathrm{Ca}^{2+}$ pumping was blocked by thapsigargin we find that CALHM1 increased the concentration gradient-driven, passive (leak) $\mathrm{Ca}^{2+}$ fluxes through the ER membrane (Fig. 3 ), and that both influx and efflux were similarly increased, to about twice the control values (Fig. 3B). The increase of the leak rates in the PM-permeabilized cells was similar to the one found in the experiments with intact cells (Fig. 2D). The normal pathway for $\mathrm{ER} \mathrm{Ca}^{2+}$ leak has not been established [47] even though many candidates have been proposed [10, 27, 48]. It is not likely that CALHM1 plays an important role as a universal ER leak channel, since it is weakly expressed in non-neural tissues [24].

The increase of $\mathrm{Ca}^{2+}$ entry and the resulting increase of $\left[\mathrm{Ca}^{2+}\right]_{\mathrm{C}}$ in CALHM1-expressing cells (Fig. 1) should result in an increase of $\left[\mathrm{Ca}^{2+}\right]_{\mathrm{ER}}$. An excessive filling of the ER has been proposed as part of some working hypothesis for the pathogenesis of $\operatorname{AD}[2,18]$. On the contrary, we find that the steadystate $\left[\mathrm{Ca}^{2+}\right]_{\mathrm{ER}}$ level was decreased in the CALHM1-expressing cells (Fig. 2). This outcome cannot be explained only by the increase of the ER leak (Fig. 3) that parallels the PM leak (Fig. 1) [24]; since ER uptake is proportional to $\left[\mathrm{Ca}^{2+}\right]^{2}[49]$, it should be very strongly affected by the increase of $\left[\mathrm{Ca}^{2+}\right]_{\mathrm{C}}$. Therefore, an increase rather than a decrease $\left[\mathrm{Ca}^{2+}\right]_{\mathrm{ER}}$ should be expected from a parallel increase of the leak of both the PM and the ER membrane. Using the PM-permeabilized cells we find that the active ER uptake is deeply modified in the CALHM1-expressing cells, with a decrease of both $\mathrm{V}_{\max }$ and $\mathrm{Ca}^{2+}$ affinity (Fig. 4C). The combined action of both, increased ER leak and decreased ER pumping, decreases the steady state $\left[\mathrm{Ca}^{2+}\right]_{\mathrm{ER}}$ by 6-7 fold at the normal resting $\left[\mathrm{Ca}^{2+}\right]_{\mathrm{C}}$ of $10^{-7} \mathrm{M}$ (Fig. $4 \mathrm{D})$. As a result of these alterations $\left[\mathrm{Ca}^{2+}\right]_{\mathrm{ER}}$ should be permanently low in CALHM1-expressing cells. This decrease of $\left[\mathrm{Ca}^{2+}\right]_{\mathrm{ER}}$ could activate store-operated $\mathrm{Ca}^{2+}$ entry [50] and this action could contribute to increase the $\mathrm{PM} \mathrm{Ca}{ }^{2+}$ entry and the resting $\left[\mathrm{Ca}^{2+}\right]_{\mathrm{C}}$.

The decrease of $\left[\mathrm{Ca}^{2+}\right]_{\mathrm{ER}}$ activates ER stress response and UPR [26]. We find here that several UPR genes have been turned on in the CALHM1-expressing cells, nominally h-CHOP, h-ERdj4, h-GRP78 and XBP1 (Fig. 5). ER stress first helps cell survival by triggering correction mechanisms that halt translation and increase chaperone production; but if correction is not attained, then UPR initiates cell 
death programs $[28,40]$. It has been proposed that UPR may be involved in the pathogenesis of neurodegenerative diseases $[13,28,29,51,52]$. The actions of CALHM1 described here and leading to a decrease of the $\mathrm{Ca}^{2+}$ content of ER may provide a link between the calcium hypothesis and cell death and deserve further investigation.

\section{AUTHOR CONTRIBUTION}

Sonia Gallego-Sandín performed most of the experiments. Maria Teresa Alonso and Javier-GarcíaSancho provided conceptual input and designed the experiments. All authors participated in analysis, discussion and interpretation of data, revised the article, and gave final approval.. Javier García-Sancho put together all data and wrote the final form of the manuscript.

\section{ACKNOWLEDGEMENTS}

Technical assistance by Ms Miriam García Cubillas and Mr Jesús Fernández is gratefully acknowledged.

\section{FUNDING}

This work was supported by grants from the EU-ERA-Net program, the Spanish Ministerio de Ciencia e Innovación (MICINN; SAF2008-03175-E, BFU2007-60157 and BFU2010-17379), the Instituto de Salud Carlos III (RD06/0010/0000) and the Junta de Castilla y León (gr175). Sonia Gallego-Sandín was supported by a postdoctoral JAE contract from the Spanish National Research Council (CSIC). 


\section{REFERENCES}

1 Marambaud, P., Dreses-Werringloer, U. and Vingtdeux, V. (2009) Calcium signaling in neurodegeneration. Mol Neurodegener. 4, 20

2 Berridge, M. J. (2010) Calcium hypothesis of Alzheimer's disease. Pflugers Arch. 459, 441-449

3 Bezprozvanny, I. and Mattson, M. P. (2008) Neuronal calcium mishandling and the pathogenesis of Alzheimer's disease. Trends Neurosci. 31, 454-463

4 Bojarski, L., Herms, J. and Kuznicki, J. (2008) Calcium dysregulation in Alzheimer's disease. Neurochem Int. 52, 621-633

5 Sanz-Blasco, S., Valero, R. A., Rodriguez-Crespo, I., Villalobos, C. and Nunez, L. (2008) Mitochondrial $\mathrm{Ca} 2+$ overload underlies Abeta oligomers neurotoxicity providing an unexpected mechanism of neuroprotection by NSAIDs. PLoS One. 3, e2718

6 Demuro, A., Parker, I. and Stutzmann, G. E. (2010) Calcium signaling and amyloid toxicity in Alzheimer disease. J Biol Chem. 285, 12463-12468

7 Chakroborty, S., Goussakov, I., Miller, M. B. and Stutzmann, G. E. (2009) Deviant ryanodine receptormediated calcium release resets synaptic homeostasis in presymptomatic 3xTg-AD mice. J Neurosci. 29, 9458-9470

8 Supnet, C. and Bezprozvanny, I. (2010) The dysregulation of intracellular calcium in Alzheimer disease. Cell Calcium. 47, 183-189

9 Verkhratsky, A. (2005) Physiology and pathophysiology of the calcium store in the endoplasmic reticulum of neurons. Physiol Rev. 85, 201-279

10 Zhang, H., Sun, S., Herreman, A., De Strooper, B. and Bezprozvanny, I. (2010) Role of presenilins in neuronal calcium homeostasis. J Neurosci. 30, 8566-8580

11 Carvalho, C., Correia, S. C., Santos, R. X., Cardoso, S., Moreira, P. I., Clark, T. A., Zhu, X., Smith, M. A. and Perry, G. (2009) Role of mitochondrial-mediated signaling pathways in Alzheimer disease and hypoxia. J Bioenerg Biomembr. 41, 433-440

12 Duchen, M. R., Verkhratsky, A. and Muallem, S. (2008) Mitochondria and calcium in health and disease. Cell Calcium. 44, 1-5

13 Takuma, K., Yan, S. S., Stern, D. M. and Yamada, K. (2005) Mitochondrial dysfunction, endoplasmic reticulum stress, and apoptosis in Alzheimer's disease. J Pharmacol Sci. 97, 312-316

14 Thinakaran, G. and Sisodia, S. S. (2006) Presenilins and Alzheimer disease: the calcium conspiracy. Nature neuroscience. 9, 1354-1355

15 Brunello, L., Zampese, E., Florean, C., Pozzan, T., Pizzo, P. and Fasolato, C. (2009) Presenilin-2 dampens intracellular $\mathrm{Ca} 2+$ stores by increasing $\mathrm{Ca} 2+$ leakage and reducing Ca2+ uptake. J Cell Mol Med. 13, 33583369

16 Zatti, G., Burgo, A., Giacomello, M., Barbiero, L., Ghidoni, R., Sinigaglia, G., Florean, C., Bagnoli, S., Binetti, G., Sorbi, S., Pizzo, P. and Fasolato, C. (2006) Presenilin mutations linked to familial Alzheimer's disease reduce endoplasmic reticulum and Golgi apparatus calcium levels. Cell Calcium. 39, 539-550

17 Green, K. N., Demuro, A., Akbari, Y., Hitt, B. D., Smith, I. F., Parker, I. and LaFerla, F. M. (2008) SERCA pump activity is physiologically regulated by presenilin and regulates amyloid beta production. J Cell Biol. 181, 1107-1116

18 Green, K. N. and LaFerla, F. M. (2008) Linking calcium to Abeta and Alzheimer's disease. Neuron. 59, 190194

19 Smith, I. F., Hitt, B., Green, K. N., Oddo, S. and LaFerla, F. M. (2005) Enhanced caffeine-induced Ca2+ release in the 3xTg-AD mouse model of Alzheimer's disease. Journal of neurochemistry. 94, 1711-1718

20 Cheung, K. H., Shineman, D., Muller, M., Cardenas, C., Mei, L., Yang, J., Tomita, T., Iwatsubo, T., Lee, V. M. and Foskett, J. K. (2008) Mechanism of Ca2+ disruption in Alzheimer's disease by presenilin regulation of InsP3 receptor channel gating. Neuron. 58, 871-883

21 LaFerla, F. M. (2002) Calcium dyshomeostasis and intracellular signalling in Alzheimer's disease. Nat Rev Neurosci. 3, 862-872

22 Tu, H., Nelson, O., Bezprozvanny, A., Wang, Z., Lee, S. F., Hao, Y. H., Serneels, L., De Strooper, B., Yu, G. and Bezprozvanny, I. (2006) Presenilins form ER Ca2+ leak channels, a function disrupted by familial Alzheimer's disease-linked mutations. Cell. 126, 981-993

23 Zatti, G., Ghidoni, R., Barbiero, L., Binetti, G., Pozzan, T., Fasolato, C. and Pizzo, P. (2004) The presenilin 2 M239I mutation associated with familial Alzheimer's disease reduces Ca2+ release from intracellular stores. Neurobiol Dis. 15, 269-278

24 Dreses-Werringloer, U., Lambert, J. C., Vingtdeux, V., Zhao, H., Vais, H., Siebert, A., Jain, A., Koppel, J., Rovelet-Lecrux, A., Hannequin, D., Pasquier, F., Galimberti, D., Scarpini, E., Mann, D., Lendon, C., Campion, D., Amouyel, P., Davies, P., Foskett, J. K., Campagne, F. and Marambaud, P. (2008) A 
polymorphism in CALHM1 influences Ca2+ homeostasis, Abeta levels, and Alzheimer's disease risk. Cell. 133, 1149-1161

25 Lambert, J. C., Sleegers, K., Gonzalez-Perez, A., Ingelsson, M., Beecham, G. W., Hiltunen, M., Combarros, O., Bullido, M. J., Brouwers, N., Bettens, K., Berr, C., Pasquier, F., Richard, F., Dekosky, S. T., Hannequin, D., Haines, J. L., Tognoni, G., Fievet, N., Dartigues, J. F., Tzourio, C., Engelborghs, S., Arosio, B., Coto, E., De Deyn, P., Del Zompo, M., Mateo, I., Boada, M., Antunez, C., Lopez-Arrieta, J., Epelbaum, J., Schjeide, B. M., Frank-Garcia, A., Giedraitis, V., Helisalmi, S., Porcellini, E., Pilotto, A., Forti, P., Ferri, R., Delepine, M., Zelenika, D., Lathrop, M., Scarpini, E., Siciliano, G., Solfrizzi, V., Sorbi, S., Spalletta, G., Ravaglia, G., Valdivieso, F., Vepsalainen, S., Alvarez, V., Bosco, P., Mancuso, M., Panza, F., Nacmias, B., Bossu, P., Hanon, O., Piccardi, P., Annoni, G., Mann, D., Marambaud, P., Seripa, D., Galimberti, D., Tanzi, R. E., Bertram, L., Lendon, C., Lannfelt, L., Licastro, F., Campion, D., Pericak-Vance, M. A., Soininen, H., Van Broeckhoven, C., Alperovitch, A., Ruiz, A., Kamboh, M. I. and Amouyel, P. (2010) The CALHM1 P86L polymorphism is a genetic modifier of age at onset in Alzheimer's disease: a meta-analysis study. J Alzheimers Dis. 22, 247-255

26 Feng, B., Yao, P. M., Li, Y., Devlin, C. M., Zhang, D., Harding, H. P., Sweeney, M., Rong, J. X., Kuriakose, G., Fisher, E. A., Marks, A. R., Ron, D. and Tabas, I. (2003) The endoplasmic reticulum is the site of cholesterol-induced cytotoxicity in macrophages. Nat Cell Biol. 5, 781-792

27 Sammels, E., Parys, J. B., Missiaen, L., De Smedt, H. and Bultynck, G. (2010) Intracellular Ca2+ storage in health and disease: a dynamic equilibrium. Cell Calcium. 47, 297-314

28 Rutkowski, D. T. and Hegde, R. S. (2010) Regulation of basal cellular physiology by the homeostatic unfolded protein response. J Cell Biol. 189, 783-794

29 Zhao, L. and Ackerman, S. L. (2006) Endoplasmic reticulum stress in health and disease. Curr Opin Cell Biol. 18, 444-452

30 Gallego-Sandin, S., Rodriguez-Garcia, A., Alonso, M. T. and Garcia-Sancho, J. (2009) The endoplasmic reticulum of dorsal root ganglion neurons contains functional TRPV1 channels. J Biol Chem. 284, 3259132601

31 Chamero, P., Manjarres, I. M., Garcia-Verdugo, J. M., Villalobos, C., Alonso, M. T. and Garcia-Sancho, J. (2008) Nuclear calcium signaling by inositol trisphosphate in GH3 pituitary cells. In Cell Calcium ed.)^eds.). pp. 205-214

32 Manjarres, I. M., Chamero, P., Domingo, B., Molina, F., Llopis, J., Alonso, M. T. and Garcia-Sancho, J. (2008) Red and green aequorins for simultaneous monitoring of Ca2+ signals from two different organelles. Pflugers Arch. 455, 961-970

33 Manjarres, I. M., Rodriguez-Garcia, A., Alonso, M. T. and Garcia-Sancho, J. (2010) The sarco/endoplasmic reticulum $\mathrm{Ca}(2+)$ ATPase (SERCA) is the third element in capacitative calcium entry. Cell Calcium. 47, 412-418

34 Barrero, M. J., Montero, M. and Alvarez, J. (1997) Dynamics of [Ca2+] in the endoplasmic reticulum and cytoplasm of intact HeLa cells. A comparative study. J Biol Chem. 272, 27694-27699

35 Alonso, M. T., Barrero, M. J., Michelena, P., Carnicero, E., Cuchillo, I., Garcia, A. G., Garcia-Sancho, J., Montero, M. and Alvarez, J. (1999) Ca2+-induced Ca2+ release in chromaffin cells seen from inside the ER with targeted aequorin. J Cell Biol. 144, 241-254

36 Montero, M., Alonso, M. T., Carnicero, E., Cuchillo-Ibanez, I., Albillos, A., Garcia, A. G., Garcia-Sancho, J. and Alvarez, J. (2000) Chromaffin-cell stimulation triggers fast millimolar mitochondrial Ca2+ transients that modulate secretion. Nat Cell Biol. 2, 57-61

37 Bers, D. M., Patton, C. W. and Nuccitelli, R. (1994) A practical guide to the preparation of Ca2+ buffers. In Methods Cell Biol ed.)^eds.). pp. 3-29

38 Villalobos, C., Nunez, L. and Garcia-Sancho, J. (1996) Functional glutamate receptors in a subpopulation of anterior pituitary cells. FASEB J. 10, 654-660

39 Nunez, L., Senovilla, L., Sanz-Blasco, S., Chamero, P., Alonso, M. T., Villalobos, C. and Garcia-Sancho, J. (2007) Bioluminescence imaging of mitochondrial Ca2+ dynamics in soma and neurites of individual adult mouse sympathetic neurons. J Physiol. 580, 385-395

40 Lin, J. H., Li, H., Yasumura, D., Cohen, H. R., Zhang, C., Panning, B., Shokat, K. M., Lavail, M. M. and Walter, P. (2007) IRE1 signaling affects cell fate during the unfolded protein response. Science. 318, 944949

41 Lin, J. H., Li, H., Zhang, Y., Ron, D. and Walter, P. (2009) Divergent effects of PERK and IRE1 signaling on cell viability. PLoS One. 4, e4170

42 Livak, K. J. and Schmittgen, T. D. (2001) Analysis of relative gene expression data using real-time quantitative PCR and the 2(-Delta Delta C(T)) Method. Methods. 25, 402-408

43 Moreno-Ortega, A. J., Ruiz-Nuno, A., Garcia, A. G. and Cano-Abad, M. F. (2009) Mitochondria sense with different kinetics the calcium entering into HeLa cells through calcium channels CALHM1 and mutated P86L-CALHM1. Biochem Biophys Res Commun. 391, 722-726 
44 Iwawaki, T., Akai, R., Kohno, K. and Miura, M. (2004) A transgenic mouse model for monitoring endoplasmic reticulum stress. Nat Med. 10, 98-102

45 Samali, A., Fitzgerald, U., Deegan, S. and Gupta, S. (2010) Methods for monitoring endoplasmic reticulum stress and the unfolded protein response. Int J Cell Biol. 2010, 830307

46 Schroder, M. (2006) The unfolded protein response. Mol Biotechnol. 34, 279-290

47 Camello, C., Lomax, R., Petersen, O. H. and Tepikin, A. V. (2002) Calcium leak from intracellular stores-the enigma of calcium signalling. Cell Calcium. 32, 355-361

48 Guerrero-Hernandez, A., Dagnino-Acosta, A. and Verkhratsky, A. (2010) An intelligent sarco-endoplasmic reticulum $\mathrm{Ca}(2+)$ store: Release and leak channels have differential access to a concealed $\mathrm{Ca}(2+)$ pool. Cell calcium. 48, 143-149

49 Villalobos, C., Nunez, L., Montero, M., Garcia, A. G., Alonso, M. T., Chamero, P., Alvarez, J. and GarciaSancho, J. (2002) Redistribution of Ca2+ among cytosol and organella during stimulation of bovine chromaffin cells. FASEB J. 16, 343-353

50 Parekh, A. B. and Putney, J. W., Jr. (2005) Store-operated calcium channels. Physiological reviews. 85, 757810

51 Marciniak, S. J. and Ron, D. (2006) Endoplasmic reticulum stress signaling in disease. Physiol Rev. 86, 1133-1149

52 Unterberger, U., Hoftberger, R., Gelpi, E., Flicker, H., Budka, H. and Voigtlander, T. (2006) Endoplasmic reticulum stress features are prominent in Alzheimer disease but not in prion diseases in vivo. J Neuropathol Exp Neurol. 65, 348-357

\section{FIGURE LEGENDS}

Figure 1. CALHM1 increases $\mathbf{C a}^{2+}$ entry. HEK293T cells seeded in 4 well plates were cotransfected with $0.2 \mu \mathrm{g}$ of CALHM1 and $0.1 \mu \mathrm{g}$ of cytosolic GFP-aequorin (lucGA). Experiments were performed either $24 \mathrm{~h}$ (A) or $6 \mathrm{~h}$ after transfection. (B). Except when otherwise indicated, the cells were perfused with extracellular medium containing $1 \mathrm{mM} \mathrm{Ca}^{2+}(\mathrm{Ca} 1)$. $\mathrm{Ca} 0$, nominally $\mathrm{Ca}^{2+}$-free medium; $\mathrm{Ca} 2$, medium containing $2 \mathrm{mM} \mathrm{Ca}^{2+}$. Representative traces are shown. The average values of several similar experiments (in $\mu \mathrm{M}$; mean \pm s.e.m. (n)) were: In A-type experiments: resting $\left[\mathrm{Ca}^{2+}\right]_{\mathrm{C}}$ was $0.20 \pm 0.01$ (28) in control vs $1.00 \pm 0.07(29)$ in CALHM1 $(\mathrm{p}<0.0001) ; \Delta\left[\mathrm{Ca}^{2+}\right]_{\mathrm{C}}$ induced by $2 \mathrm{mM} \mathrm{Ca}^{2+}: 0.17 \pm 0.03$ (11) in control vs $2.57 \pm 0.71(12)$ in CALHM1 $(\mathrm{p}<0.0001)$. In B: resting $\left[\mathrm{Ca}^{2+}\right]_{\mathrm{C}}: 0.22 \pm 0.02(3)$ in control vs $0.38 \pm 0.02$ (3) in CALHM1 ( $<0.005) ; \Delta\left[\mathrm{Ca}^{2+}\right]_{\mathrm{C}}$ induced by $2 \mathrm{mM} \mathrm{Ca}^{2+}: 0.52 \pm 0.02$ (3) in control vs $1.20 \pm 0.06(3)$ in CALHM1 $(\mathrm{p}<0.0005)$.

Figure 2. Effects of CALHM1 on the uptake of $\mathbf{C a}^{2+}$ into the ER. (A) Cells were cotransfected with $0.8 \mu \mathrm{g}$ of either CALHM1 or the empty vector (Control), and $0.4 \mu \mathrm{g}$ of ermutGA. Six hours after transfection, the aequorin was reconstituted with coelentarazine $\mathrm{n}$ (see Methods). Cells were perfused either with regular extracellular medium containing $1 \mathrm{mM} \mathrm{Ca}^{2+}(\mathrm{Ca} 1)$ or with $\mathrm{Ca}^{2+}$ free medium $(\mathrm{Ca} 0$; containing $0.5 \mathrm{mM}$ EGTA), as shown. (B), (C) and (D) are mean \pm s.e.m. values of 9-10 experiments similar to (A). $* * *, p<0.001$.

Figure 3. Passive $\mathrm{Ca}^{2+}$ uptake and release (leak) by ER in permeabilized cells. (A) Cells cotransfected with $0.8 \mu \mathrm{g}$ of either CALHM1 or the empty vector (Control), and $0.2 \mu \mathrm{g}$ of ermutGA and cultured for 6 hours. After reconstitution with coelenterazine $\mathrm{n}$ (see Methods) cells were treated with $1 \mu \mathrm{M}$ thapsigargin for $5 \mathrm{~min}$ in $\mathrm{Ca}^{2+}$-free medium and permeabilized by perfusion with $\mathrm{Ca}^{2+}$-free intracellular-like medium containing $60 \mu \mathrm{M}$ digitonin for $2 \mathrm{~min}$ (DIGIT). Then, perfusion was switched to intracellular-like medium containing either no $\mathrm{Ca}^{2+}(\mathrm{Ca} 0 ; 0.5 \mathrm{mM}$ EGTA added) or $1 \mathrm{mM}$ $\mathrm{Ca}^{2+}(\mathrm{Ca} 1)$, as shown. (B) Initial rates (in $\mu \mathrm{M} / \mathrm{s}$ ) of ER influx or efflux. Summary of the values (mean \pm s.e.m.) obtained in 6 pairs of experiments similar to the ones shown in $(\mathrm{A}){ }^{*}, \mathrm{p}<0.05 ; * *$, $\mathrm{p}<0.005$. In 4 similar experiments using $0.5 \mathrm{mM} \mathrm{Ca}^{2+}$ (instead of $1 \mathrm{mM}$ ) the values obtained were (control vs. experimental; mean \pm s.e.m.): influx, $3.95 \pm 0.19$ vs $10.19 \pm 0.86(\mathrm{p}<0.005)$; efflux, $22.18 \pm 2.48$ vs $56.35 \pm 8.56(\mathrm{p}<0.05)$.

Figure 4. Kinetics of $\mathbf{C a}^{2+}$ uptake by the $\mathbf{E R}$ in permeabilized cells. Cells were transfected with 0.8 $\mu \mathrm{g}$ of either CALHM1 or the empty pcDNA3 vector (Control) and $0.4 \mu \mathrm{g}$ of ermutGA, and cultured for $6 \mathrm{~h}$. After reconstitution with coelenterazine $\mathrm{n}$ (see Methods) cells were permeabilized in $\mathrm{Ca}^{2+}$-free 
intracellular-like medium containing $60 \mu \mathrm{M}$ digitonin for 2 minutes (not shown in the figure). Then the uptake was started by perfusion with intracellular-like solution containing known $\left[\mathrm{Ca}^{2+}\right]$ (buffered with EGTA; see Methods). (A) and (B) illustrate typical traces with 0.02 to $20 \mu \mathrm{M}\left[\mathrm{Ca}^{2+}\right]$ (equivalent in these experiments to $\left.\left[\mathrm{Ca}^{2+}\right]_{\mathrm{C}}\right)$. (C) Double logarithmic plot of rate of uptake vs $\left[\mathrm{Ca}^{2+}\right]_{\mathrm{C}}$. Values correspond to mean \pm s.e.m. of 3-14 experiments. The traces were adjusted to the equation:

$\mathrm{V}=\left(\mathrm{V}_{\max } \cdot\left(\left[\mathrm{Ca}^{2+}\right]_{\mathrm{ER}}\right)^{\mathrm{n}}\right) /\left(\mathrm{K}_{0.5}+\cdot\left(\left[\mathrm{Ca}^{2+}\right]_{\mathrm{ER}}\right)^{\mathrm{n}}\right)$; the estimated values for $\mathrm{V}_{\max }, \mathrm{K}_{0.5}$ and $\mathrm{n}$ were: $50,0.3$ and 2 in the control and 20, 0.9 and 1.6 in the CALHM1-expressing cells, respectively. (D) Changes of the $\left[\mathrm{Ca}^{2+}\right]_{\mathrm{ER}}$ reached at the steady state as a function of $\left[\mathrm{Ca}^{2+}\right]_{\mathrm{C}}$ (in $\mu \mathrm{M}$ ); the values are mean \pm s.e.m. of several experiments (number of values shown on the top of the columns) of cell transfected with either CALHM1 (filled bars) or the empty vector (open bars). ${ }^{* * *}, \mathrm{p}<0.001$.

Figure 5. CALHM1 expression induces ER stress. (A and B) CALHM1-Cherry chimera increases $\mathrm{P}_{\mathrm{Ca}}$ in the PM and in the ER. Cells transfected with $0.2 \mu \mathrm{g}$ of CALHM1-Cherry and cultured for $24 \mathrm{~h}$ were loaded with fura-2 and perfused with regular extracellular medium containing different $\mathrm{Ca}^{2+}$ concentrations and agonists as shown: $\mathrm{Ca} 0, \mathrm{Ca}^{2+}$-free (0.5 mM EGTA); $\mathrm{Ca} 10: 10 \mathrm{mM} \mathrm{Ca}{ }^{2+} ; \mathrm{Ca} 1,1$ $\mathrm{mM} \mathrm{Ca}$; a representative experiment is shown. The red and the black traces are the average of 20 Cherry-positive cells and 35 Cherry-negative cells, respectively, present in the same microscope field. (B) Mean \pm s.e.m. of 4 similar experiments. (C) Fluorescence images in CALHM1-Cherry and XBP1venus cotransfected cells. Images of blue (DAPI; all the nuclei), green (XBP1-venus; ER stress marker), and red fluorescences (CALHM1-Cherry) are shown to illustrate cell localization of the different markers. The last image was obtained by merging the first three (D) Comparison of the percentage of XBP1 expression in control (unfilled bar; cells transfected with Cherry and expressing red fluorescence) and CALHM1 expressing cells (red bar, cells transfected with CALHM1-Cherry and expressing red fluorescence). Values are mean \pm s.e.m. of 6 pairs of experiments. In each experiment, 5 different fields observed with a 20x objective were examined and counted. $* * *, p<0.0001$. (E) Induction of h-Chop, h-ERdj4 and h-GRP78. For these experiments, HEK293T were transfected with $8 \mu \mathrm{g}$ of either CALHM1 or the empty vector. After $24 \mathrm{~h}$ of culture, the expression of h-CHOP, hERdj4 and h-GRP78 was measured by quantitative RT-PCR and expressed as CALHM1/Control ratio (see Methods). Mean \pm s.e.m. of 18 determinations. ${ }^{* * *}, \mathrm{p}<0.001$. 


\section{FIG. 1}
A. $24 \mathrm{~h}$
B. $6 \mathrm{~h}$
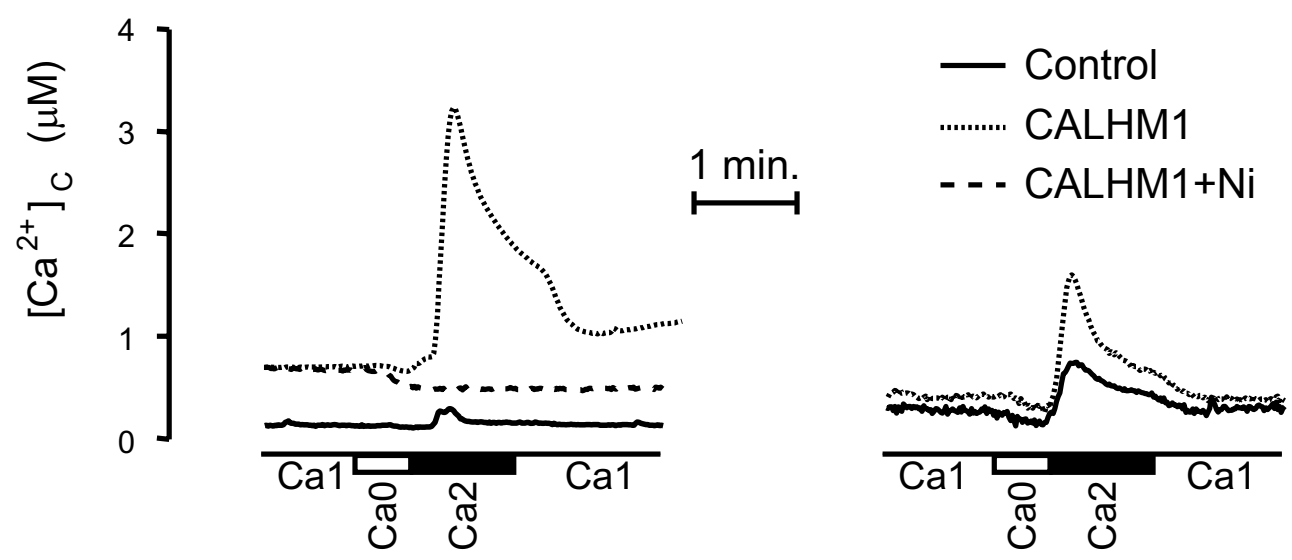

Figure 1. CALHM1 increases $\mathrm{Ca}^{2+}$ entry. HEK293T cells seeded in 4 well plates were cotransfected with $0.2 \mu \mathrm{g}$ of CALHM1 and $0.1 \mu \mathrm{g}$ of cytosolic GFP-aequorin (lucGA).

Experiments were performed either $24 \mathrm{~h}(\mathrm{~A})$ or $6 \mathrm{~h}$ after transfection. (B). Except when otherwise indicated, the cells were perfused with extracellular medium containing $1 \mathrm{mM} \mathrm{Ca}^{2+}$ (Ca1). Ca0, nominally $\mathrm{Ca}^{2+}$-free medium; $\mathrm{Ca} 2$, medium containing $2 \mathrm{mM} \mathrm{Ca}^{2+}$.

Representative traces are shown. The average values of several similar experiments (in $\mu \mathrm{M}$; mean \pm s.e.m. (n)) were: In A-type experiments: resting $\left[\mathrm{Ca}^{2+}\right]_{\mathrm{c}}: 0.20 \pm 0.01(28)$ in control vs $1.00 \pm 0.07(29)$ in CALHM1 ( $<<0.0001) ; \Delta\left[\mathrm{Ca}^{2+}\right]_{\mathrm{C}}$ induced by $2 \mathrm{mM} \mathrm{Ca}^{2+}: 0.17 \pm 0.03(11)$ in control vs $2.57 \pm 0.71(12)$ in CALHM1 $(p<0.0001)$. In B: resting $\left[\mathrm{Ca}^{2+}\right]_{\mathrm{c}}: 0.22 \pm 0.02(3)$ in control vs $0.38 \pm 0.02(3)$ in CALHM1 $(p<0.005) ; \Delta\left[\mathrm{Ca}^{2+}\right]_{c}$ induced by $2 \mathrm{mM} \mathrm{Ca}^{2+}: 0.52 \pm 0.02$ (3) in control vs $1.20 \pm 0.06(3)$ in CALHM1 $(p<0.0005)$. 
FIG. 2

A.

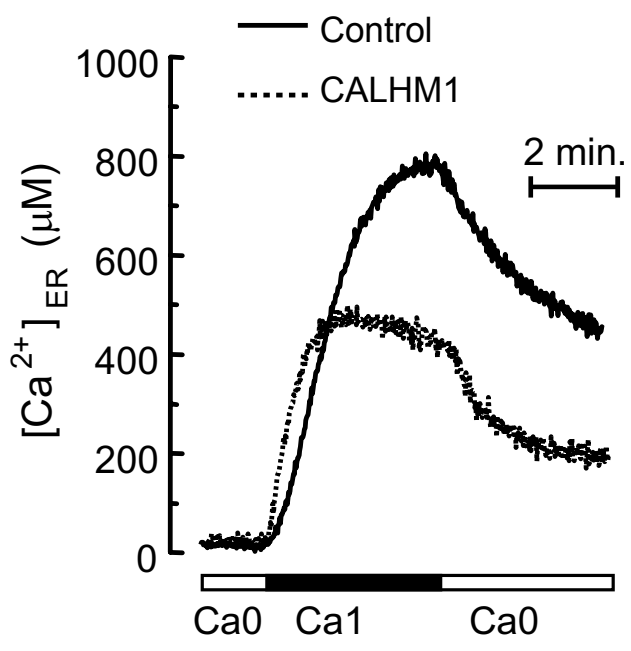

B.

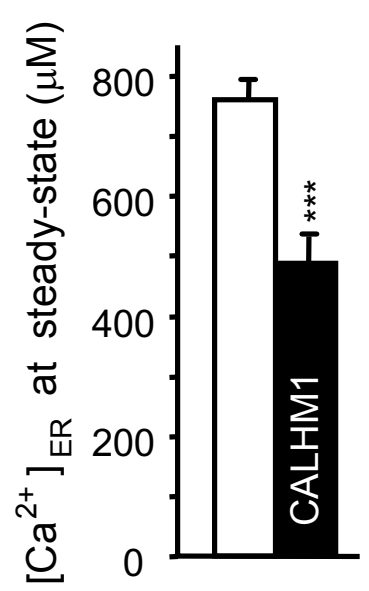

C.

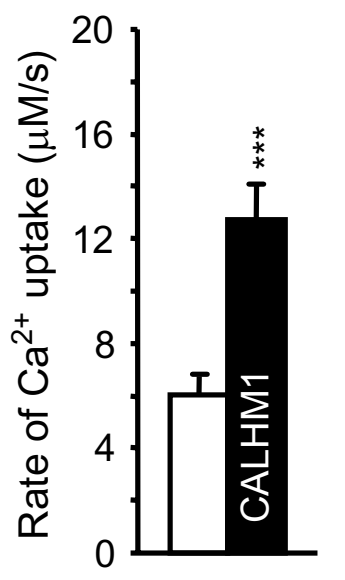

D.

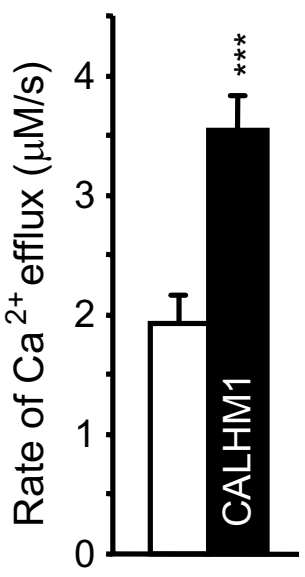

Figure 2. Effects of CALHM1 on the uptake of $\mathrm{Ca}^{2+}$ into the ER. (A) Cells were cotransfected with $0.8 \mu \mathrm{g}$ of either CALHM1 or the empty vector (Control), and $0.4 \mu \mathrm{g}$ of ermutGA. Six hours after transfection, the aequorin was reconstituted with coelentarazine $n$ (see Methods). Cells were perfused either with regular extracellular medium containing 1 $\mathrm{mM} \mathrm{Ca}^{2+}(\mathrm{Ca} 1)$ or with $\mathrm{Ca}^{2+}$ free medium (Ca0; containing $\left.0.5 \mathrm{mM} \mathrm{EGTA}\right)$, as shown. (B), (C) and (D) are mean \pm s.e.m. values of 9-10 experiments similar to $(A) .{ }^{* * *}, p<0.001$. 


\section{FIG. 3}
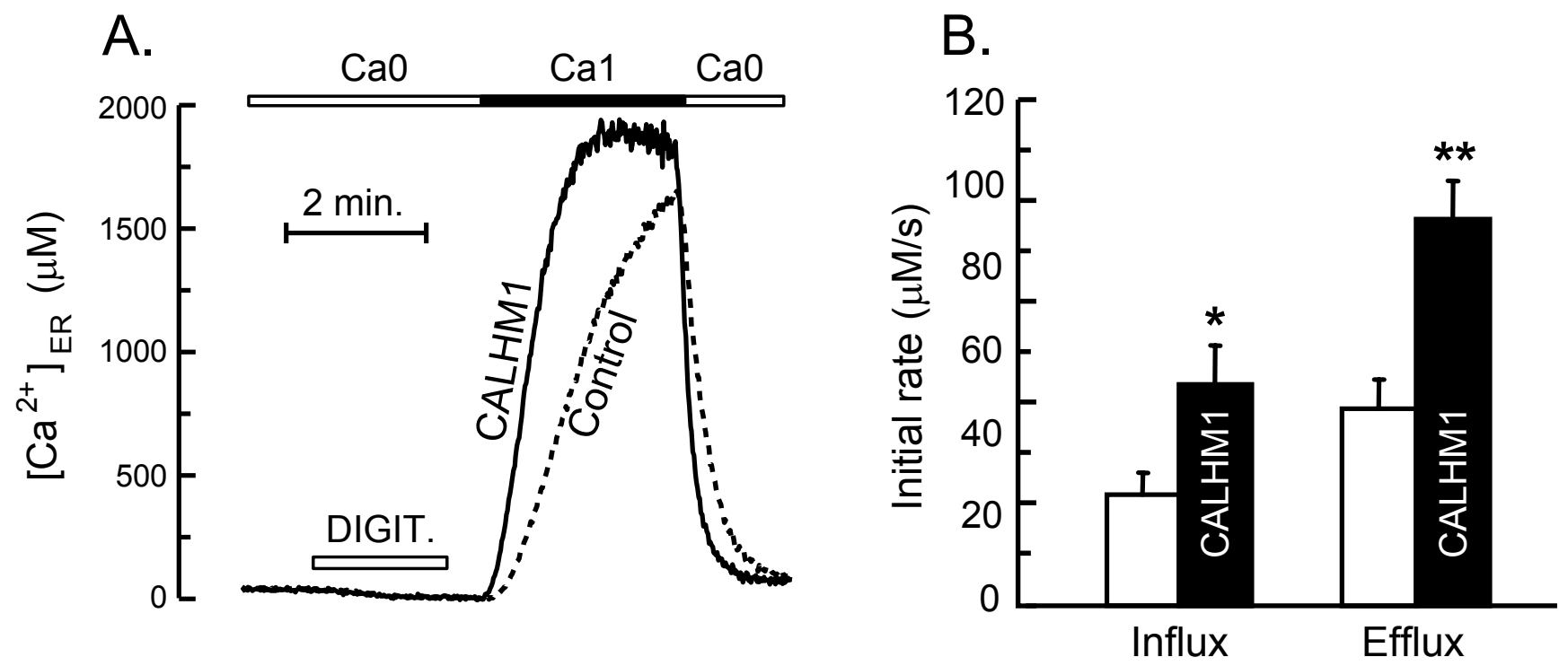

Figure 3. Passive $\mathrm{Ca}^{2+}$ uptake and release (leak) by ER in permeabilized cells. (A) Cells cotransfected with $0.8 \mu \mathrm{g}$ of either CALHM1 or the empty vector (Control), and $0.2 \mu \mathrm{g}$ of ermutGA and cultured for 6 hours. After reconstitution with coelenterazine $n$ (see Methods) cells were treated with $1 \mu \mathrm{M}$ thapsigargin for $5 \mathrm{~min}$ in $\mathrm{Ca}^{2+}$-free medium and permeabilized by perfusion with $\mathrm{Ca}^{2+}$-free intracellular-like medium containing $60 \mu \mathrm{M}$ digitonin for 2 min (DIGIT). Then, perfusion was switched to intracellular-like medium containing either no $\mathrm{Ca}^{2+}\left(\mathrm{Ca} 0 ; 0.5 \mathrm{mM}\right.$ EGTA added) or $1 \mathrm{mM} \mathrm{Ca}^{2+}(\mathrm{Ca} 1)$, as shown. (B) Initial rates (in $\mu \mathrm{M} / \mathrm{s}$ ) of ER influx or efflux. Summary of the values (mean \pm s.e.m.) obtained in 6 pairs of experiments similar to the ones shown in $(A) .{ }^{*}, p<0.05 ;{ }^{* *}, p<0.005$. In 4 similar experiments using $0.5 \mathrm{mM} \mathrm{Ca}^{2+}$ (instead of $1 \mathrm{mM}$ ) the values obtained were (control vs. experimental; mean \pm s.e.m.): influx, $3.95 \pm 0.19$ vs $10.19 \pm 0.86$ ( $p<0.005$ ); efflux, $22.18 \pm 2.48$ vs $56.35 \pm 8.56(p<0.05)$. 
A. Control

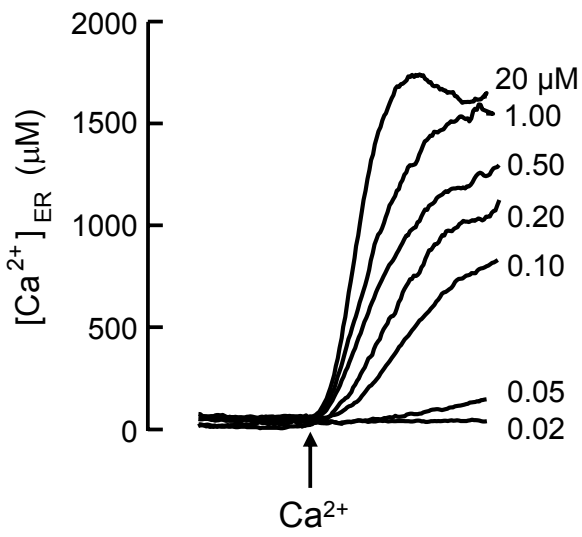

B. CALHM1

$1 \mathrm{~min}$.

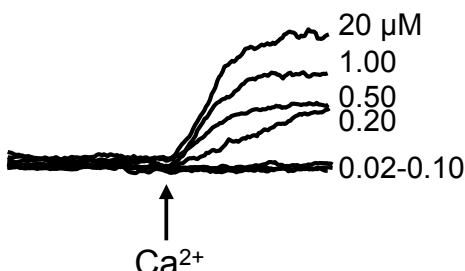

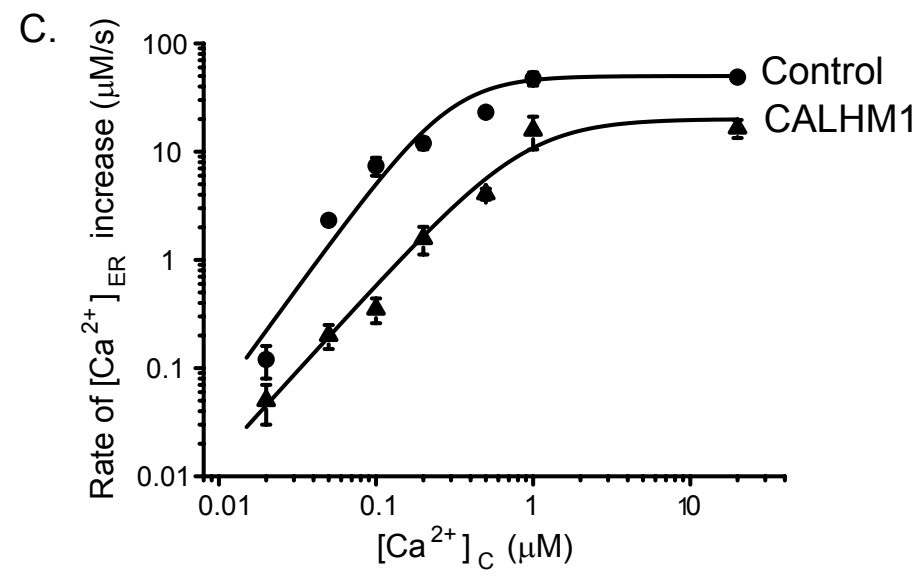

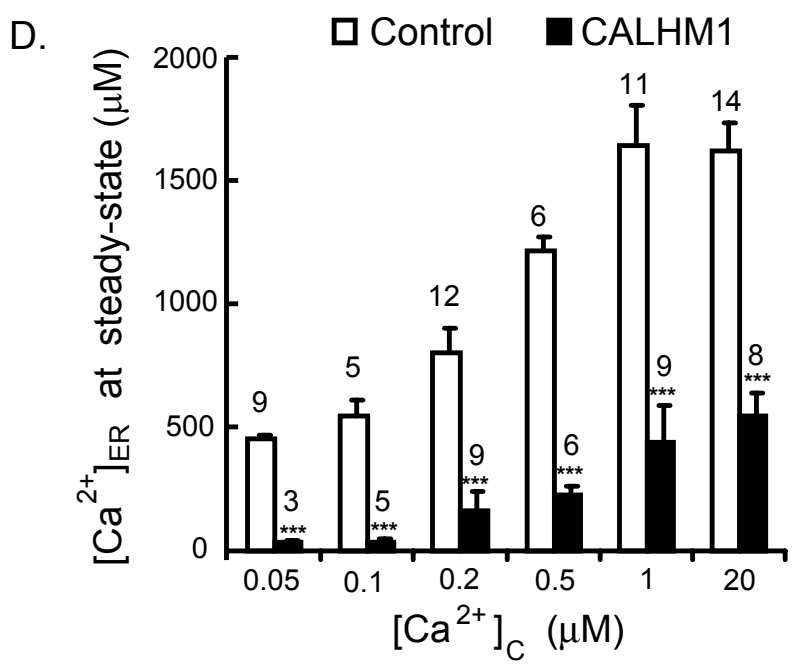

Figure 4. Kinetics of $\mathrm{Ca}^{2+}$ uptake by the ER in permeabilized cells. Cells were transfected with $0.8 \mu \mathrm{g}$ of either CALHM1 or the empty pcDNA3 vector (Control) and $0.4 \mu \mathrm{g}$ of ermutGA, and cultured for $6 \mathrm{~h}$. After reconstitution with coelenterazine $\mathrm{n}$ (see Methods) cells were permeabilized in $\mathrm{Ca}^{2+}$-free intracellular-like medium containing $60 \mu \mathrm{M}$ digitonin for 2 minutes (not shown in the figure). Then the uptake was started by perfusion with intracellular-like solution containing known $\left[\mathrm{Ca}^{2+}\right]$ (buffered with EGTA; see Methods). (A) and (B) illustrate typical traces with 0.02 to $20 \mu \mathrm{M}\left[\mathrm{Ca}^{2+}\right]$ (equivalent in these experiments to $\left.\left[\mathrm{Ca}^{2+}\right]_{\mathrm{C}}\right)$. (C) Double logarithmic plot of rate of uptake vs $\left[\mathrm{Ca}^{2+}\right]_{\mathrm{c}}$. Values correspond to mean \pm s.e.m. of 3-14 experiments. The traces were adjusted to the equation: $\mathrm{V}=\left(\mathrm{V}_{\max } \cdot\left(\left[\mathrm{Ca}^{2+}\right]_{E R}\right)^{\mathrm{n}}\right) /\left(\mathrm{K}_{0.5}+\cdot\left(\left[\mathrm{Ca}^{2+}\right]_{E R}\right)^{\mathrm{n}}\right)$; the estimated values for $\mathrm{V}_{\max }, \mathrm{K}_{0.5}$ and $\mathrm{n}$ were: $50,0.3$ and 2 in the control and 20, 0.9 and 1.6 in the CALHM1-expressing cells, respectively. (D) Changes of the $\left[\mathrm{Ca}^{2+}\right]_{E R}$ reached at the steady state as a function of $\left[\mathrm{Ca}^{2+}\right]_{C}$ (in $\mu \mathrm{M}$ ); the values are mean \pm s.e.m. of several experiments (number of values shown on the top of the columns) of cell transfected with either CALHM1 (filled bars) or the empty vector (open bars). ${ }^{* * *}, p<0.001$. 
A.

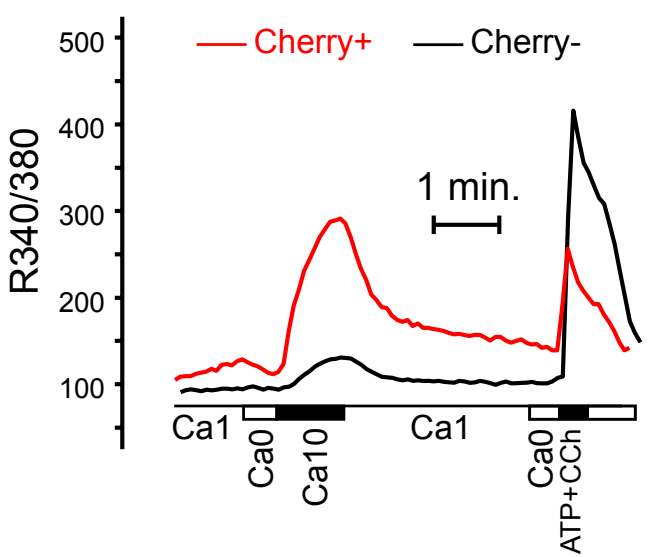

c.

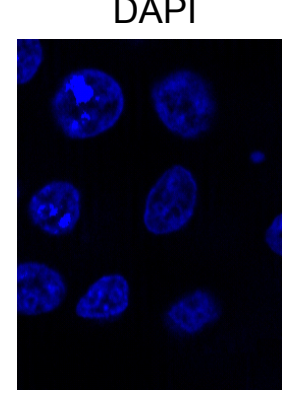

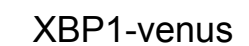
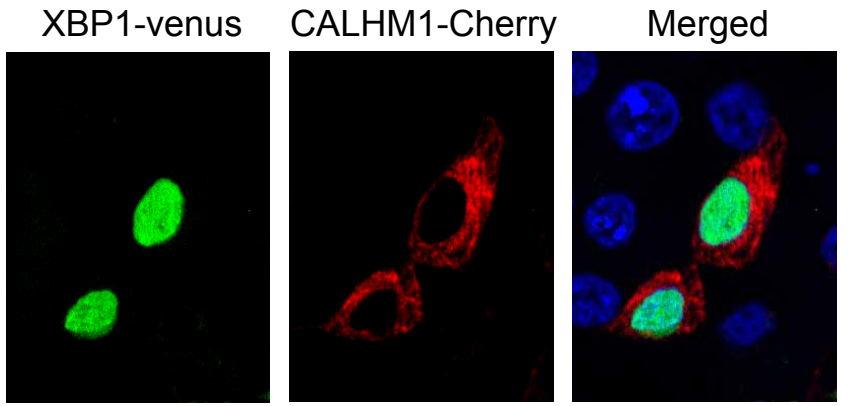

E.

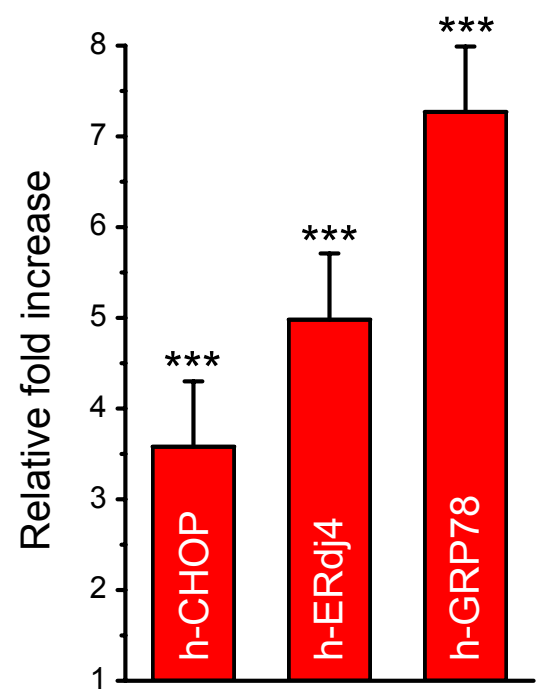

Figure 5. CALHM1 expression induces ER stress. (A and B) CALHM1-Cherry chimera increases $\mathrm{P}_{\mathrm{Ca}}$ in the PM and in the ER. Cells transfected with $0.2 \mu \mathrm{g}$ of CALHM1-Cherry and cultured for $24 \mathrm{~h}$ were loaded with fura-2 and perfused with regular extracellular medium containing different $\mathrm{Ca}^{2+}$ concentrations and agonists as shown: $\mathrm{CaO}, \mathrm{Ca}^{2+}$-free $(0.5 \mathrm{mM}$ EGTA); Ca10: $10 \mathrm{mM} \mathrm{Ca}{ }^{2+}$; Ca1, $1 \mathrm{mM} \mathrm{Ca}$; a representative experiment is shown. The red and the black traces are the average of 20 Cherry-positive cells and 35 Cherry-negative cells, respectively, present in the same microscope field. (B) Mean \pm s.e.m. of 4 similar experiments. (C) Fluorescence images in CALHM1-Cherry and XBP1-venus cotransfected cells. Images of blue (DAPI; all the nuclei), green (XBP1-venus; ER stress marker), and red fluorescences (CALHM1-Cherry) are shown to illustrate cell localization of the different markers. The last image was obtained by merging the first three (D) Comparison of the percentage of XBP1 expression in control (unfilled bar; cells transfected with Cherry and expressing red fluorescence) and CALHM1 expressing cells (red bar, cells transfected with CALHM1-Cherry and expressing red fluorescence). Values are mean \pm s.e.m. of 6 pairs of experiments. In each experiment, 5 different fields observed with a 20x objective were examined and counted. ${ }^{* *}, p<0.0001$. (E) Induction of $h$-Chop, h-ERdj4 and h-GRP78. For these experiments, HEK293T were transfected with $8 \mu \mathrm{g}$ of either CALHM1 or the empty vector. After $24 \mathrm{~h}$ of culture, the expression of h-CHOP, h-ERdj4 and h-GRP78 was measured by quantitative RT-PCR and expressed as CALHM1/Control ratio (see Methods). Mean \pm s.e.m. of 18 determinations. ${ }^{* \star *}, p<0.001$. 